\title{
COMPARISON OF EXTERNAL FIXATION AND PLASTER CASTING RESULTS IN DISTAL RADIUS METAPHYSIS FRACTURES THAT ARE NOT SUITABLE FOR OPEN REDUCTION
}

\author{
Açık Redüksiyona Uygun Olmayan Radius Distali Metafiz Kırıklarında Eksternal Fiksasyon ile \\ Alçı Döküm Sonuçlarının Karşılaştırılması
}

Kerim ÖNER $^{1}$ (D), Muhammet Salih AYAS ${ }^{2}$

${ }^{1}$ Karadeniz Teknik Üniversitesi Tıp Fakültesi, Ortopedi ve Travmatoloji A.D., TRABZON, TÜRKIYYE

${ }^{2}$ T.C. Sağlık Bakanlığı Erzurum Bölge EAH., Ortopedi ve Travmatoloji Kliniğ̈i, ERZURUM, TÜRKIYYE

Objective: We aimed to compare the radiographic and functional results of extra-articular metaphyseal fractures of the distal radius treated with closed reduction and plaster casting (CRPC) and bridging external fixation (EF).

Material and Methods: This retrospective study included 65 patients with distal radius fractures. The mean age of the patients was 55 years. Patients were divided into two groups, which were called the CRPC group and bridging EF group. All fractures were AO/OTA type A3. All patients were evaluated with Green and O'Brien Score modified by Cooney, Mayo Wrist Score and The Disabilities of the Arm, Shoulder, and Hand (DASH) at the end of the first year.

Results: The mean age was $54.32 \pm 8.61$ years in the CRPC group and 56.65 \pm 8.31 years in the Bridging EF group. The mean followup time was $24.06 \pm 8.67$ months in the CRPC group and $24.88 \pm 9.2$ months in the bridging EF group. When the fractures were compared radiologically during the evaluation at the end of the first year, radial inclination and radial length results in the bridging EF group were statistically significant compared to the CRPC group. When the range of motions was compared in the fractures during the clinical examination, they were statistically significant in the bridging EF group compared to the CRPC group. There was no statistical significance in Green and Mayo scores in terms of the scoring between the groups. DASH score was $10.88 \pm 2.99$ in the CRPC group and $5.73 \pm 2.57$ in the bridging EF group, and it was statistically significant $(\mathrm{p}<0.001)$.

Conclusion: Bridging EF treatment can be recommended as one of the primary treatment options in AO/OTA type A3 radius fractures, whose soft tissue does not allow open surgery, because it is a less invasive technique and provides successful clinical results.

Keywords: DASH, distal radius fractures, extra-articular, external fixation, plaster casting
Amaç: Kapalı redüksiyon ve alçı (KRA) ve köprü eksternal fiksasyon (EF) ile tedavi edilen distal radius eklem dış1 metafizer kırıklarının radyografik ve fonksiyonel sonuçlarını karşılaştırmayı amaçladık.

Gereç ve Yöntemler: Bu retrospektif çalışmaya distal radius kırığı olan 65 hasta dahil edildi. Hastaların ortalama yaşı 55 idi. Hastalar KRA grubu ve köprü EF grubu olarak adlandırılan iki gruba ayrıldı. Tüm kırıklar AO/OTA tip A3 idi. Tüm hastalar, birinci yılın sonunda Cooney tarafından modifiye edilen Green ve O'Brien Skoru, Mayo Bilek Skoru ve Kol, Omuz ve El Engellilikleri (DASH) ile değerlendirildi.

Bulgular: Ortalama yaş KRA grubunda $54.32 \pm 8.61$ yıl, köprü EF grubunda $56.65 \pm 8.31$ y1l idi. Ortalama takip süresi KRA grubunda $24.06 \pm 8.67$ ay, köprü EF grubunda $24.88 \pm 9.2$ aydı. Birinci yılın sonunda yapılan değerlendirmede kırıklar radyolojik olarak karşılaştırıldığında, köprü oluşturan EF grubunda radyal eğim ve radyal uzunluk sonuçları KRA grubuna göre istatistiksel olarak anlamlı bulundu. Klinik muayene sirasında kırıkların hareket aralığ karşılaştırıldığında, köprü EF grubunda KRA grubuna göre istatistiksel olarak anlaml bulundu. Green ve Mayo skorlarında gruplar arası skorlama açısından istatistiksel olarak anlamlı bulunmadi. DASH skoru KRA grubunda $10.88 \pm 2.99$, köprü EF grubunda $5.73 \pm 2.57$ idi ve istatistiksel olarak anlamlıyd $1(\mathrm{p}<0.001)$.

Sonuç: Daha az invaziv bir teknik olması ve başarılı klinik sonuçlar sağlaması nedeniyle yumuşak dokusu açık cerrahiye izin vermeyen AO/OTA tip A3 radius kırıklarında birincil tedavi seçeneklerinden biri olarak köprüleyici EF tedavisi önerilebilir.

Anahtar Kelimeler: DASH, distal radius kırı̆̆g, eklem dışı, eksternal fiksasyon, alçı 


\section{INTRODUCTION}

Distal radius fractures are common fractures and they constitute $15 \%$ of all fractures $(1,2)$. Treatment options for displaced distal radius fractures are closed reduction and plaster casting (CRPC), bridging external fixation (EF) and/or pin fixation, open reduction and, pin or plate fixation $(3,4)$. However, it is not clear which surgical intervention would be the best option and would yield better results (5).

Traditional CRPC techniques aim to provide a reduction with ligamentotaxis. It provides secondary bone healing by preserving the fracture hematoma. Plaster care, patient compliance, and follow-up are the most important factors to be considered $(6,7)$. In the bridging EF technique, ligamentotaxis is used to restore and maintain the anatomic alignment. Fixation is strengthened by adding percutaneous $\mathrm{K}$ wires where necessary. It is a closed and/or minimally open technique that protects the fracture hematoma (8). This technique is very useful in unstable, fragmented metaphyseal fractures of the radius distal where osteosynthesis is not possible with a locked plate as volar and the soft tissue is not suitable for open surgery $(9,10)$.

There are many studies in the literature comparing techniques related to distal radius fracture surgery; however, the number of studies comparing CRPC and bridging $\mathrm{EF}$ techniques is relatively low compared to other studies (11-14). In this study, we aimed to compare the results of bridge EF treatment and CRPC treatment in AO Foundation and Orthopedic Trauma Association (AO/OTA) classification type $\mathrm{A} 3$ radius fractures whose soft tissue does not allow open surgery.

\section{MATERIALS AND METHODS}

The study protocol was approved by the local ethics committee (Yozgat Bozok University Faculty of Medicine Ethics Committee of Clinical Research, date: 28.05.2020, issue number: 2017-KAEK189_2020.05.28_07). Written informed consent for the surgical procedure was obtained from each patient. Patients, who were treated with conservative and bridging EF due to extra-articular distal radial fractures between May 2016 and March 2019, were evaluated. CRPC and surgical procedures of the patients were performed by a single surgical team.

This retrospective study included patients over 18 years old with distal radius type A3 fracture in AO/OTA classification, who were treated with CRPC and bridging EF, and had at least 1-year follow-up.

Patients with AO/OTA type B and type $\mathrm{C}$ fractures and fractures in the surface of the joint, bilateral fractures, multi-trauma, open fractures, and pathological fractures, distal radioulnar joint pathology, accompanying carpal, metacarpal or phalanx fracture, old fracture history in the same extremity, patients who received treatment with open reduction and internal fixation technique, patients who experienced an accompanying neurovascular injury, had cognitive disorders; and patients whose data were not available were identified as the criteria for exclusion.

After evaluation, 65 patients who met the inclusion criteria, were included in the analysis. There were 31 patients in the CRPC group and 34 patients in the EF group. The decision on bridging EF or CRPC was taken according to the configuration of the fracture, condition of the soft tissue, comorbidity of the patient, and the preference of the patients after acknowledgment. Surgeons who performed the treatment and the followup were competent in training, experience, and knowledge of surgical options as well as the process of informing the patient during decision-making.

Patients in the CRPC group were treated as outpatients. Patients, who underwent surgery with bridging EF, were followed up in the hospital for 1 day.

Age, gender, location of the fracture (right-left), trauma type (fall from a height, simple fall, occupational accident, in-vehicle traffic accident, and non-vehicle traffic accident) and follow-up time were recorded for 
all patients. Table 1 presents the details of the demographic data belonging to both groups.

\section{Closed Reduction and Plaster Casting}

CRPC was applied to the fractures of all patients in the emergency clinic. A splint was initially applied to 12 patients with excessive soft tissue swelling. Plaster casting was applied to these patients at least 1 week after trauma when soft tissue swelling decreased. Before plaster casting, patients with deterioration in control radiography were applied closed reduction again.

In the CRPC group, a short-arm plaster casting was applied in neutral flexion/extension of the wrist. If the radiographies were not acceptable after the procedure, closed reduction and plaster casting were performed again. Acceptable criteria were identified as minimum $0^{\circ}$ of a volar tilt, minimum $10 \mathrm{~mm}$ of radial height, and minimum $10^{\circ}$ of radial inclination $(7,15)$.

Eight patients with comorbid diseases, who did not meet the acceptance criteria and did not desire to undergo surgery, were followed up in the position obtained after the last closed reduction. Patients were checked every week for the first 4 weeks. Clinical and radiological follow-ups were made in the 6th week. At the end of week 6 , the plasters were removed and rehabilitation was started.

Table 1: Demographic data of patients with distal radius fracture

\begin{tabular}{llccc}
\hline & & CRCP $(\mathbf{n}=31)$ & EF(n=34) & p value \\
\hline Age $($ mean \pm SD) & & $54.32 \pm 8.61$ & $56.65 \pm 8.31$ & 0.273 \\
\hline Mean follow up, month $($ mean \pm SD) & & $24.06 \pm 8.67$ & $24.88 \pm 9.2$ \\
\hline Gender & Male & 14 & 16 & 0.878 \\
& Female & 17 & 18 & 0.531 \\
\hline Side & Right & 17 & 18 & 10 \\
& Left & 14 & 18 \\
\hline Type of trauma & Falling from high & 6 & 3 \\
& Simple falling & 13 & 3 & 2 \\
& Work accident & 8 & 1 \\
\hline
\end{tabular}

\section{Bridging External Fixation}

Bridging EF was applied to all patients under general or local anesthesia. The modular type was used as the bridging EF (Anatomi, Konya, Turkey). Firstly, a miniincision was made approximately $5 \mathrm{~cm}$ proximal to the fracture. Two pins were placed in the radius diaphysis, crossing both cortices. Then, the process was continued in the distal fracture. A mini-incision was made to the 2nd metacarpal proximal level. Two pins were placed, crossing both cortices.
After the Bridging external fixator was placed, hyperpronation, flexion, and ulnar deviation were performed as the closed reduction maneuver. The position of the fracture was evaluated using fluoroscopy. Acceptable criteria were determined as minimum $0^{\circ}$ of a volar tilt, minimum $10 \mathrm{~mm}$ of radial height, and minimum $10^{\circ}$ of radial inclination under fluoroscopy $(7,15)$. Percutaneous K-wire was applied to 15 patients to increase the stability of the fixation.

Pin care for bridging EF was performed with physiological saline daily. All patients were discharged 
1 day after the surgery. After discharge, patients were informed about the maintenance of the external fixator. The fixators of all patients, who were treated with bridging external fixators, were mobilized from the hinge point in the $3 \mathrm{rd}$ week. Fixator and applied $\mathrm{K}$ wires were removed at the orthopedic outpatient clinic at the 6th week and rehabilitation started.

\section{Post-Operative Management and Follow-Up Assessment}

In the CRPC group, physiotherapy of the finger and elbow joints was started immediately after plaster casting. Absolute elevation was applied to the patients especially in the first 3 days. In the 6 th week, the plaster was removed and wrist joint physiotherapy was started. Physiotherapy of the finger and elbow joints was started the day after the surgical intervention in the bridging EF group. Wrist motion exercises were started in the $3 \mathrm{rd}$ week with a dynamic external fixator. Fixator and applied $\mathrm{K}$ wires were removed at the orthopedic outpatient clinic at the 6th week and rehabilitation started. All patients had similar follow-up protocols. After their casts were removed, all patients were evaluated clinically and radiologically at the 6th week, 9 th week, 12th week, 6th month, 1 year, and the last follow-ups.

Functional measurements were performed at the end of the 1st year of patient follow-up by an independent physiotherapist, who was not included in the study. The goniometer was used to evaluate the range of motion of the wrist. The loss of power was first measured on the wrist without fractures and then on the fractured side, using a hydraulic hand dynamometer (Model SH 5001, Saehan Corporation, Masan, Korea). The difference between the normal side was expressed in percentages. In anteroposterior and lateral radiographies during the follow-ups, the union was evaluated according to bone continuity in at least 3 of 4 cortices. Radiographic results were calculated according to various radiological parameters (Radial inclination, volar tilt, radial height) on the radiographies taken at the end of the first year of patient follow-up. All results were evaluated by a single surgeon to minimize the error between observers. All patients were asked to complete the Green and O'Brien Score modified by Cooney, The Disabilities of the Arm, Shoulder, and Hand (DASH) and Mayo Wrist Score surveys at the end of the first year after the surgery $(16,17)$. Statistical data of all patients were constructed by considering their clinical and radiological evaluations at the end of the first year.

\section{Statistical Analysis}

While conducting the statistics of the study, numerical data were given as a mean and standard deviation in the descriptive statistics, and the categorical data were given as numbers and percentages. The distribution of numerical data was examined with histogram graphics. Numerical data were analyzed by the Student t-test in two separate groups. The analysis of the data that did not conform to the normal distribution was performed with the Mann-Whitney $U$ test. Categorical data were compared using Chi-square and Fisher's Exact tests. The significance value of $\mathrm{p}$ was accepted as $<0.05$. SPSS 23.0 package program was used in the analyses.

\section{RESULTS}

The data of 65 patients, who met the criteria, were evaluated retrospectively. The mean age of patients in the CRPC group was $54.32 \pm 8.61$ years and $56.65 \pm 8.31$ years in the bridging EF group. The mean follow-up period was $24.06 \pm 8.67$ months (min: 12 , $\max : 40$ ) in the CRPC group and 24.88 \pm 9.2 months (min: 12, max: 40) in the bridging EF group.

Data and union periods regarding all fractures at the end of the first year are presented in Table 2. The scores regarding the mean range of motion in the wrist and the loss of grip strength in the final follow-up are presented in Table 3.

Table 2: Radiographic results of patients with distal radius fracture 


\begin{tabular}{lccc}
\hline & \multicolumn{3}{c}{ Patient Groups } \\
\cline { 2 - 4 } & CRPC $(\mathrm{n}=31)$ & EF $(\mathrm{n}=34)$ & $\mathrm{p}$ value \\
\cline { 2 - 4 } & Mean $\pm \mathrm{SD}$ & $\mathrm{Mean} \pm \mathrm{SD}$ & 0.130 \\
\hline Volar tilt & $12.61 \pm 1.97$ & $11.79 \pm 2.29$ & $<0.001$ \\
Radial inclination & $11.97 \pm 3.27$ & $15.09 \pm 2.36$ & 0.006 \\
Radial length & $9.19 \pm 2.49$ & $10.76 \pm 1.98$ & 0.014 \\
Healing time of radius fractures & $6.97 \pm 0.83$ & $7.71 \pm 1.42$ & \\
\hline
\end{tabular}

Table 3: Functional results of patients with distal radius fracture

\begin{tabular}{lccc}
\hline & \multicolumn{3}{c}{ Patient Groups } \\
\cline { 2 - 4 } & CRPC $(\mathrm{n}=31)$ & EF $(\mathrm{n}=34)$ & p value \\
\cline { 2 - 4 } & Mean $\pm \mathrm{SD}$ & Mean $\pm \mathrm{SD}$ & 0.006 \\
\hline Volar flexion & $62.1 \pm 11.01$ & $68.68 \pm 7.61$ & $<0.001$ \\
Dorsal flexion & $51.45 \pm 7.21$ & $62.79 \pm 8.36$ & 0.810 \\
Radial deviation & $17.1 \pm 5.59$ & $16.76 \pm 5.48$ & 0.271 \\
Ulnar deviation & $18.23 \pm 6.77$ & $20.15 \pm 7.12$ & 0.007 \\
Pronation & $56.45 \pm 9.14$ & $63.09 \pm 9.13$ & $<0.001$ \\
Supination & $57.42 \pm 8.64$ & $70.88 \pm 8.91$ & 0.001 \\
Loss of grip strength $(\%)$ & $14.35 \pm 3.81$ & $11.03 \pm 3.64$ & 0.610 \\
Green and O'Brien Score & $76.61 \pm 8.88$ & $77.79 \pm 9.62$ & 0.239 \\
Mayo Wrist Score & $74.52 \pm 8.30$ & $77.35 \pm 10.67$ & $<0.001$ \\
DASH Score & $10.88 \pm 2.99$ & $5.73 \pm 2.57$ & \\
\hline
\end{tabular}

When the fractured sides were compared radiologically, the results of radial inclination $(\mathrm{p}<0.001)$ and radial length $(p=0.006)$ in the EF group were statistically significant compared to the CRPC group. There was no difference in both groups in terms of volar tilt results $(p=$ 0.130). No arthritis was observed in patients radiologically.

The ranges of motion were compared for the fractured sides during the examination at the end of the first year; and volar flexion $(\mathrm{p}=0.006)$, dorsiflexion $(\mathrm{p}<0.001)$, pronation $(\mathrm{p}=0.007)$ and supination $(\mathrm{p}<0.001)$ were statistically significant in the bridging EF group compared to the CRPC group. There was no statistical difference between the radial and ulnar deviation. When both groups were compared at the end of the first year, there was no statistical significance in Green and Mayo scores $(p>0.05)$. The difference in the DASH score was statistically significant in the bridging $\mathrm{EF}$ group compared to the CRPC group $(\mathrm{p}<0.001)$ Table 2.

In the CRPC group, 12 patients had splint due to soft tissue swelling, and plaster casting was performed to these patients before the end of the first week after trauma. There was deterioration in the reductions of 11 
patients and they did not comply with the conservative treatment criteria; therefore, they were treated with remanipulation and re-casting during the first-week examination. Conservative acceptance criteria were not met in 8 of these patients; and the follow-up was continued with plaster as they did not accept surgical intervention. Plaster discomfort occurred in 6 patients and plaster modifications were performed. Neurological complications did not develop in any of the patients.

In the bridging EF group, 3 patients had superficial percutaneous pin site infections requiring local care and antibiotics. They recovered with treatment and care. Chronic osteomyelitis was not observed. Regional pain syndrome developed in 9 patients ( 7 in the CRPC group, 2 in the bridging EF group), and their treatments were arranged by the physical therapy department. There was no statistical significance between the groups in terms of regional pain syndrome $(\mathrm{p}=0.055)$.

\section{DISCUSSION}

In this study, the data of patients with metaphyseal fragmented fractures in the distal radius, who were treated with CRPC and bridging EF, were evaluated. Better range of motion data, better radiological data, less power loss, and better DASH score data were obtained in the bridging EF group $(\mathrm{p}<0.05)$. Radial inclination and radial height values were found to be significantly better in the bridging EF group compared to the CRPC group. Accordingly, it can be argued that EF technique is more effective in maintaining the current position $(13,18)$.

Even if the plastering technique is performed by experienced clinicians and reduction is provided appropriately in fractures with disintegration in the metaphyseal region and prone to displacement, it may not be continued effectively with plaster casting treatment $(7,19,20)$. Therefore, we believe that surgical techniques should be preferred in the treatment of metaphyseal fragment fractures unless there is an obstacle for operation. We found volar flexion, dorsiflexion, pronation, and supination range of motions significantly higher in bridging EF treatment compared to the CRPC group $(\mathrm{p}<0.05)$.

Aktekin(11) et al. compared the clinical and radiological results of CRPC and $\mathrm{EF}$ in their retrospective and nonrandomized study on 46 patients over 65 years of age. They reported better results in the EF group radiologically. However, they did not find a clinically significant difference. Our study included a larger group and the mean age was 55 years. Radiological data, range of wrist motion data, and clinical scoring results (DASH only) were statistically significant in the EF group compared to CRPC. Our study, which had a lower mean age range, produced similar results with the study of Aktekin et al. This suggests that the results of the two treatment techniques we compared did not differ significantly according to age.

In their study involving 90 patients over the age of 65 , Egol(12) et al. reported that there was no difference between the two groups at the end of the first year and their clinical scores were similar; however, the grip strength and radiological data were better in the EF group. In our study, we obtained better grip strength and radiological data in the EF group similarly during our evaluation at the end of the first year. However, the range of motion was better in the EF group and significantly different from the CRPC group in our study $(p<0.05)$. Better joint range of motion in the EF group could be an important reason for our clinical results to be better in this group.

We compared this study with the complications of similar studies in the literature. In the study by Howard (13) et al. comparing randomized control, CRPC, and EF on 50 patients, 2 patients in the EF group had pin site infection and radial neuritis. In the CRPC group, 3 patients had radial neuritis, 4 patients had median nerve compression, 2 patients had ulnar nerve compression, and 1 patient had extensor pollicis longus rupture. They stated that they did not observe regional pain syndrome 
in any of the patients. In another study, Egol(12) et al. compared CRPC and EF and they reported carpal tunnel syndrome and tendinitis in both groups. In addition, they administered additional surgeries in 4 patients in the EF group (ulna distal excision, plaque screw osteosynthesis removing EF, capsulotomy, and synovectomy, and carpal tunnel surgery). They did not observe infections in any of their patients. In our study, we did not observe any neurological complications in any of the groups. We did not apply any additional surgical procedures to any of the groups. In the EF group, we observed superficial pin site infection in 3 patients. All patients were treated with antibiotics and local wound dressings. In our study, 7 patients in the CRPC group and 2 patients in the EF group developed regional pain syndrome, which was different from other studies. This data is not statistically significant; however, we believe that this occurred due to the immobilization of the CRPC group for a longer period of time. All of these 9 patients had fully recovered at the end of the first year. In order to reduce this risk, EF could primarily be suggested as a minimally invasive technique that allows patients to start moving earlier.

In their study on 40 patients comparing CRPC and EF, Morani(14) et al. observed that reduction had deteriorated in 4 patients in the CRPC group during follow-up. Functional results were poor in these patients. Kreder et al. recommended EF in patients with a reduction during conservative follow-up (18). In addition, McQueen et al. reported that the results would not be good after repeated manipulations (20). In our study, manipulation was repeated in a total of 12 patients in the CRPC group. Conservative acceptance criteria could not be met in 8 patients; and they were followed up with the position obtained in the last manipulation since they had comorbid diseases and did not wish to have surgery. According to our data at the end of the first year, we had satisfactory scores in the CRPC group as well in terms of the Green and O'Brien Score modified by Cooney (76.61 \pm 8.88$)$, Mayo Wrist Score
(74.52 \pm 8.30$)$ and DASH (10.88 \pm 2.99$)$. CRPC treatment is not a primary preference in the extra-articular fragmented metaphyseal fractures of distal radius; however, it can be preferred and would produce successful results in the presence of conditions that prevent operation.

There was no statistical difference between our groups in terms of other clinical scoring systems except for the DASH score. In contrast, in their studies evaluating the clinical results of patients after distal radius fractures, Souer(17) et al. reported that pain and comprehension power, which were the parameters of the Mayo wrist and wrist strength, were affected by psychosocial factors in certain individuals, and therefore could affect the results.As a result, they stated that the DASH score was more suitable for evaluation. We agree with Souer et al. based on our clinical and statistical results. Our results demonstrated a statistically significant difference in the DASH score between the groups $(\mathrm{p}<0.001)$. We are in favor of using DASH scoring in the clinical evaluation of distal radius fractures in order to make better inferences.

The limitations of our study can be listed as being a retrospective study and a relatively low number of patients.

Bridging EF treatment can be recommended as one of the primary treatment options in AO/OTA type A3 radius fractures, whose soft tissue does not allow open surgery, because it is a less invasive technique and provides successful clinical results.

Conflict of Interest: The authors have no conflicts of interest to declare.

Support and Acknowledgment: There is no funding source.

Researchers' Contribution Rate Statement: ConceptDesign: KO, MSA; Data Collection and Processing: KO; Analysis and Interpretation: KO, MSA; Literature Search: KO, MSA; Writing Manuscript: KO, MSA; 
Critical Review: KO, MSA. All authors have read and approved the final form of the manuscript.

Ethics Committe Aproval: Yozgat Bozok University Clinical Research Ethics Committee, date: 28.05.2020, issue number: 2017-KAEK-189_2020.05.28_07

\section{REFERENCES}

1. Talmaç MA, Görgel MA, Kanar M, Tok O, Özdemir HM. Comparison of three surgical methods in the treatment of intraarticular comminuted distal radius fractures: Volar locking plate, non-bridging external fixator, and bridging external fixator. Eklem Hast ve Cerrahisi. 2019;30(3):224-32.

2. Turan S, Çankaya D, Yinolmaz S, Karakuş D, Dündar A, Özdemir G. Effect of ulnar styloid fracture on outcomes after conservative treatment of distal radius fracture. Eklem Hast ve Cerrahisi. 2016;27(2):87-93.

3. Ju JH, Jin GZ, Li GX, Hu HY, Hou RX. Comparison of treatment outcomes between nonsurgical and surgical treatment of distal radius fracture in elderly: a systematic review and meta-analysis. Langenbeck’s Arch Surg. 2015;400(7):767-79.

4. Schneppendahl J, Windolf J, Kaufmann RA. Distal radius fractures: Current concepts. J Hand Surg Am. 2012;37(8):1718-25.

5. Abe Y, Doi K, Kuwata N, Yamamoto H, Sunago K, Kawai S. Surgical options for distal radial fractures: Indications and limitations. Arch Orthop Trauma Surg. 1998;117(4-5):188-92.

6. Rodríguez-Merchán EC. Management of comminuted fractures of the distal radius in the adult: Conservative or surgical? Clin Orthop Relat Res. 1998;(353):53-62.

7. Cherubino P, Bini A, Marcolli D. Management of distal radius fractures: Treatment protocol and functional results. Injury. 2010;41(11):1120-6.
8. Rhee PC, Medoff RJ, Shin AY. Complex distal radius fractures: An anatomic algorithm for surgical management. J Am Acad Orthop Surg. 2017;25(2):77-88.

9. Seitz WH, Froimson AI, Leb R, Shapiro JD. Augmented external fixation of unstable distal radius fractures. J Hand Surg Am. 1991;16(6):1010-6.

10. Gausepohl T, Pennig D, Mader K. Principles of external fixation and supplementary techniques in distal radius fractures. Injury. 2000;31(Suppl.1):5670.

11. Aktekin CN, Altay M, Gursoy Z, Aktekin LA, Ozturk AM, Tabak AY. Comparison between external fixation and cast treatment in the management of distal radius fractures in patients aged 65 years and older. J Hand Surg Am. 2010;35(5):736-42.

12. Egol KA, Walsh M, Romo-Cardoso S, Dorsky S, Paksima N. Distal radial fractures in the elderly: operative compared with nonoperative treatment $\mathbf{J}$ Bone Joint Surg Am. 2010;92(9):1851-7.

13. Howard PW, Stewart HD, Hind RE, Burke FD. External fixation or plaster for severely displaced comminuted Colles' fractures? A prospective study of anatomical and functional results. J Bone Jt Surg - Ser B. 1989;71(1):68-73.

14. Moroni A, Vannini F, Faldini C, Pegreffi F, Giannini S. Cast vs external fixation: A comparative study in elderly osteoporotic distal radial fracture patients. Scand J Surg. 2004;93(1):64-7.

15. Dario P, Matteo G, Carolina C, Marco G, Cristina D, Daniele $\mathrm{F}$ et al. Is it necessary to restore radial anatomic parameters after distal radius fractures? Injury. 2014;45(S6):S21-6.

16. Kwok IHY, Leung F, Yuen G. Assessing results after distal radius fracture treatment: a comparison of objective and subjective tools. Geriatr Orthop Surg Rehabil. 2011;2(4):155-60. 
17. Souer JS, Lozano-Calderon SA, Ring D. Predictors of wrist function and health status after operative treatment of fractures of the distal radius. J Hand Surg Am. 2008;33(2):157.e1-157.e8.

18. Kreder HJ, Agel J, McKee MD, Schemitsch EH, Stephen D, Hanel DP. a randomized, controlled trial of distal radius fractures with metaphyseal displacement but without joint incongruity: closed reduction and casting versus closed reduction, spanning external fixation, and optional percutaneous K-wires. J Orthop Trauma. 2006;20(2):115-21.

19. Pattee GA, Thompson GH. Anterior and posterior marginal fracture-dislocations of the distal radius. An analysis of the results of treatment. Clin Orthop Relat Res. 1988;(231):183-95.

20. McQueen MM, MacLaren A, Chalmers J. The value of remanipulating Colles' fractures. J Bone Jt Surg Ser B. 1986;68(2):232-3. 